\title{
Amaranth, quinoa, and millet growth and development under different water regimes in the Brazilian Cerrado
}

\author{
Adilson Jayme-Oliveira(1), Walter Quadros Ribeiro Júnior(2), Maria Lucrécia Gerosa Ramos(3), \\ Adley Camargo Ziviani( ${ }^{(4)}$ and Adriano Jakelaitis ${ }^{(5)}$
}

\begin{abstract}
(1)Instituto Federal de Brasília, Campus Planaltina, Caixa Postal 08202, CEP73380-900 Brasília, DF, Brazil. E-mail: adilson.oliveira@ifb.edu.br (2)Embrapa Cerrados, Caixa Postal 08223, CEP 73310-970 Brasília, DF, Brazil. E-mail: walter.quadros@embrapa.br (3)Universidade de Brasília, Faculdade de Agronomia e Medicina Veterinária, Instituto Central de Ciências, CEP 70910-900 Brasília, DF, Brazil. E-mail: lucreciaunb@gmail.com ${ }^{(4)}$ Instituto Federal do Triângulo Mineiro, Campus Uberaba, Rua João Batista Ribeiro, no 4.000, Distrito Industrial II, CEP 38064-790 Uberaba, MG, Brazil. E-mail: adley@iftm.edu.br ${ }^{(5)}$ Instituto Federal Goiano, Campus Rio Verde, Rodovia Sul-Goiana, Km 01, CEP 75901-970 Rio Verde, GO, Brazil. E-mail: adrianojakelaitis@gmail.com
\end{abstract}

Abstract - The objective of this work was to evaluate the growth dynamics of the cover plants amaranth (Amaranthus cruentus), quinoa (Chenopodium quinoa), and millet (Pennisetum glaucum) in a Typic Acrustox, under different water regimes in the Brazilian Cerrado. The cultivation was carried out in the winter, with reduced rainfall, which facilitated the application of varying irrigation depths to the different crops. Water regimes denominated lower, lower middle, upper middle, and upper - corresponding to $217,386,563$, and $647 \mathrm{~mm}$ water depths, respectively - were tested by means of an irrigation bar composed of sprinklers with different flow rates. Plant growth was quantified by weekly collections. Amaranth was the most responsive plant to water. Quinoa showed the best performance in the treatment with the upper-middle water level among the other evaluated species. Millet showed thermal sensitivity for cultivation in the winter, making grain production unfeasible; however, it showed exceptional ability to produce biomass even in the treatment with higher water deficit.

Index terms: Amaranthus cruentus, Chenopodium quinoa, Pennisetum glaucum, Oxisol, water stress.

\section{Crescimento e desenvolvimento de amaranto, quinoa e milheto sob diferentes regimes hídricos no Cerrado}

\begin{abstract}
Resumo - O objetivo deste trabalho foi avaliar a dinâmica do crescimento das plantas de cobertura amaranto (Amaranthus cruentus), quinoa (Chenopodium quinoa) e milheto (Pennisetum glaucum) em Latossolo Vermelho, sob diferentes regimes hídricos no Cerrado. O cultivo foi realizado no inverno, com pluviosidade reduzida, o que facilitou a aplicação de lâminas de irrigação nas diferentes culturas. No experimento foram avaliados regimes hídricos intitulados de inferior, médio inferior, médio superior e superior, correspondentes à aplicação respectiva de 217, 386, 563 e $647 \mathrm{~mm}$ de lâminas de água, por meio de uma barra irrigadora composta por aspersores de diferentes vazões. O crescimento das plantas foi quantificado mediante coletas com periodicidade semanal. $\mathrm{O}$ amaranto foi a planta mais responsiva à água. A quinoa apresentou o melhor desempenho no tratamento com nível de água médio superior entre as espécies avaliadas. O milheto apresentou sensibilidade térmica ao cultivo no inverno, o que inviabilizou a produção de grãos; porém, mostrou excepcional aptidão quanto à produção de biomassa, inclusive no tratamento com maior deficit hídrico.
\end{abstract}

Termos para indexação: Amaranthus cruentus, Chenopodium quinoa, Pennisetum glaucum, Latossolo, estresse hídrico.

\section{Introduction}

Agriculture in the Cerrado is concentrated on few species of economic interest, such as soybean, corn, cotton, and forage crops (Acompanhamento..., 2015). Diversification is desirable, in order to contribute to the minimization of soil degradation and pest proliferation caused by monoculture.
The Cerrado shows a very pronounced dry period with severe water limitations (Assad et al., 1993), and irrigation is not always feasible, which stimulates research to select more adapted genotypes to rainfed conditions. In this sense, it is imperative that the selection of promising crops assess the behavior of genotypes under water deficit conditions. Pseudocereals may become an option not only for grain 
production, but also for biomass and forage production (Spehar \& Trecenti, 2011). In a pioneering work with pseudocereals, Teixeira et al. (2003) evaluated the development of Amaranthus cruentus accessions, and reported good adaptation of this species to the Cerrado; its cultivar BRS Alegria shows an average productivity of 2,359 $\mathrm{kg} \mathrm{ha}^{-1}$ (Spehar et al., 2003), and can reach up to $3,000 \mathrm{~kg} \mathrm{ha}^{-1}$ (Ferreira et al., 2014). Some Amaranthus species showed contrasting stomatal conductance under conditions of water deficit (Liu \& Stützel, 2002), and good osmotic adjustment capacity in response to drought (Liu \& Stützel, 2004), suggesting a possible crop adaptation in the off-season period.

Chenopodium quinoa is a pseudocereal native to the Andes that is adapted to water stress conditions (Spehar et al., 2014). However, in the Mediterranean region, reductions in quinoa productivity were observed when water stress occurred in the grain filling (Lavini et al., 2014), despite the occurrence of interaction with saline stress in this region. It has been found that quinoa cultivars under water stress decrease their photosynthetic rate and leaf area (Fghire et al., 2015), and other authors have obtained lower productivity under water stress associated with changes in temperature and luminosity (Hirich et al., 2014). Choukr-Allah et al. (2016), in a review of quinoa for the Middle East and Central Asia, found not only responses to irrigation, but also adaptability to marginal water conditions.

Millet, Pennisetum glaucum (L.) R. Br., is an alternative for agricultural diversification and soil protection (Spehar \& Trecenti, 2011). It is a traditional crop in Africa and wide adopted in India, with adaptation to locations under abiotic stresses (The world..., 1996). Despite millet's rusticity, its genetic improvement has provided that under favorable conditions its production increases have favored the expansion of cultivation in Brazil (Pereira Filho, 2009). Jimenez et al. (2008) compared millet and quinoa as cover plants, and the first one stood out for its root system, even in a simulating treatment of compacted soil. Water stress can affect plants by reducing the plant height, relative growth rate, cell growth, photosynthetic rate, and the respiration activation (Hýsková et al., 2014). Cultivated plants have several mechanisms of adaptation to water deficit, but the responses are complex and adaptation is attributed to the ability of plants to control water losses by transpiration, which depends on the stomatal sensitivity and greater capacity of water absorption by the root system, among other factors (Khan et al., 2010).

The objective of this work was to evaluate the growth dynamics of the cover plants amaranth, quinoa, and millet, in a Latossolo Vermelho under different water levels in the Brazilian Cerrado.

\section{Materials and Methods}

The experiment was conducted at Embrapa Cerrados $\left(15^{\circ} 35^{\prime} \mathrm{S}, 47^{\circ} 42^{\prime} \mathrm{W}\right)$, on a Latossolo Vermelho distrófico (Typic Acrustox) with clayey texture. The soil analysis showed the following: $\mathrm{pH}, 5.79 ; \mathrm{Ca}, 3.31 \mathrm{cmol}_{\mathrm{c}}$ $100 \mathrm{~cm}^{-3} ; \mathrm{Mg}, 1.40 \mathrm{cmol}_{\mathrm{c}} 100 \mathrm{~cm}^{-3} ; \mathrm{P}, 48.20 \mathrm{mg} \mathrm{L}^{-1} ; \mathrm{K}$, $217.04 \mathrm{mg} \mathrm{L}^{-1} ; \mathrm{H}+\mathrm{Al}, 4.50 \mathrm{cmol}_{\mathrm{c}} 100 \mathrm{~cm}^{-3}$; and organic matter, $25.8 \mathrm{~g} \mathrm{~kg}^{-1}$.

Sowing was carried out in May 2014 for millet 'BRS 1501', amaranth 'BRS Alegria', and quinoa 'BRS Piabiru'. Each plot consisted of eight rows of $8 \mathrm{~m}$ length, with $0.4 \mathrm{~m}$ spacing. The experiment was set up in four randomized complete blocks with subdivided plots; the main plot was the water depth, and the subplots were the different crops.

The fertilizer formulation 04-14-08 at $700 \mathrm{~kg} \mathrm{ha}^{-1}$ (28 $\mathrm{kg} \mathrm{ha}^{-1} \mathrm{~N}, 98 \mathrm{~kg} \mathrm{ha}^{-1} \mathrm{P}_{2} \mathrm{O}_{5}$, and $56 \mathrm{~kg} \mathrm{ha}^{-1} \mathrm{~K}_{2} \mathrm{O}$ ) was used at planting, and $100 \mathrm{~kg} \mathrm{ha}^{-1} \mathrm{~N}$ (urea) was applied at 25 days after emergence (DAE). Plant thinning was done at $30 \mathrm{DAE}$, to maintain 10 plants per linear meter. The water regimes (WR) were obtained using a $40 \mathrm{~m}$ wide bar irrigation sprinkler, model 36/42 (IrrigaBrasil, Pinhais, PR, Brazil) connected to the TurboMaq 75/GB reel (IrrigaBrasil, Pinhais, PR, Brazil), with adjustable speed. Irrigation was conducted according to the Irrigation Monitoring program in the Cerrado (Monitoramento..., 2016). Up to $30 \mathrm{DAE}$, irrigation was uniform. After this period, the line source methodology was adapted (Hanks et al., 1976), modified by the introduction of an irrigation bar, using sprinklers with different flow rates. Overlap between the sprinklers promoted a decreasing gradient of water from the central area of the bar to the edge of the experiment. For each side of the bar, 4 plots measuring $3.2 \mathrm{~m}$ wide and $1 \mathrm{~m}$ apart were plotted, representing the water regimes. During the uniform irrigation phase there was $21 \mathrm{~mm}$ rainfall on June 3, which summed with the irrigations provided an average of $149 \mathrm{~mm}(1 / 3$ of the total average) from May 14 to June 17, 2014. The accumulated irrigation 
depth during 118 days showed a sigmoidal behavior (Figure 1), with the outermost collector of the assay accumulating $155 \mathrm{~mm}$, while the central area showed the greatest water depth with an estimate of $671 \mathrm{~mm}$.

The inflection point, from increasing to decreasing rates, was estimated at $355 \mathrm{~mm}$ (associated with WR lower medium). The four treatments were: lower (LL), lower medium (LM), upper medium (UM), and upper (UU) accumulating water depths at 217, 386, 563 and $647 \mathrm{~mm}$ during the assays, respectively. Plant growth was evaluated in weekly collections at $30,37,43,51,58$, $64,71,78,85,92,99,106$, and 120 DAE. Three plants were sampled in the four central lines of the plot, and the following variables were evaluated: plant height; basal area growth; number of leaves; and dry weight of stem, leaves and reproductive structures. After the $71 \mathrm{DAE}$, the inflorescences dry weight of three plants sampled per experimental unit were collected for obtaining, and tracking, the progression of grain filling. To obtain the dry matter, expressed in grams per plant, the collected material was dehydrated in an oven at $65^{\circ} \mathrm{C}$. The productive components evaluated in time were subjected to analysis of variance, using the software Sisvar 5.3. Adjustments were evaluated by linear (linear and quadratic) and nonlinear (sigmoidal) models in Sigmaplot, and the best equations were selected according to the significance of the coefficients, and according to the magnitude of

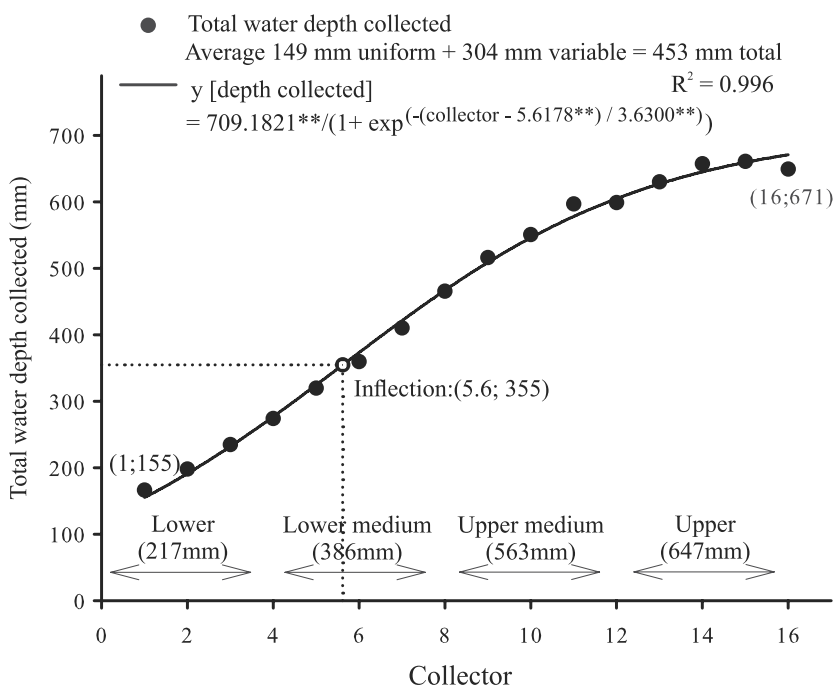

Figure 1. Total water depth collected (mm) among the water regimes (WRs): lower, lower middle, upper middle, and upper WRs correspond to 217, 386, 563, and $647 \mathrm{~mm}$ water depths, respectively. the determination coefficients, in order to explain the behavior of the component in time.

The behavior of the components dismembered for the WRs and represented with the same model were evaluated by comparing the parameters determined from the adjusted mathematical equation, as follows: linear adjustments, value of the productive component in the last collection or the angular coefficient (first derivative); quadratic adjustments, coordinates at the estimated maximum of the equation (first derivative equal to zero); sigmoidal adjustments, estimated coordinates at the point of inflection (maximum value of the first derivative), or value of the productive component in the last collection; no mathematical adjustments, the means were compared.

The WRs that did not show similar behaviors were compared with the value estimated in the last collection. Four months after sowing, and three months from the beginning of the application of the different water depths, soil moisture was evaluated on a gravimetric basis, with three replicates for each plot at three soil depths.

\section{Results and Discussion}

Although cover crop cultivation occurs in the summer, the experiment was conducted in the winter to isolate the effect of water from that of heat. However, in the winter, the lower temperatures affected the vegetative period and maturity (Costa \& Priesnitz, 2014).

At the end of the assay, soil moisture was similar at all depths for the water regimes (WRs) - upper (UU), upper medium (UM), and lower medium (LM) -, making it unnecessary to measure moisture at layers deeper than $30 \mathrm{~cm}$ (Table 1). Only the most stressed

Table 1. Soil gravimetric moisture content (\%), at 120 days after emergence (DAE) in the central area of the water regimes at three depths.

\begin{tabular}{lcccc}
\hline Water regime & \multicolumn{3}{c}{ Sample layer $(\mathrm{cm})$} & \multirow{2}{*}{ Average } \\
\cline { 2 - 4 } & $0-10$ & $10-20$ & $20-30$ & \\
\hline Upper (UU, 647 mm) & $22.58 \mathrm{aA}$ & $23.75 \mathrm{aA}$ & $23.08 \mathrm{aA}$ & 23.14 \\
Upper medium (UM, 563 mm) & $23.83 \mathrm{aA}$ & $23.00 \mathrm{aA}$ & $22.42 \mathrm{aA}$ & 23.08 \\
Lower medium (LM, 386 mm) & $16.17 \mathrm{bA}$ & $16.58 \mathrm{bA}$ & $17.17 \mathrm{bA}$ & 16.64 \\
Lower (LL, 271 mm) & $11.25 \mathrm{cB}$ & $14.58 \mathrm{cA}$ & $15.58 \mathrm{bA}$ & 13.81 \\
\hline Average & 18.46 & 19.48 & 19.56 & 19.17 \\
\hline
\end{tabular}

${ }^{(1)}$ Means followed by equal letters, lowercase in the columns and uppercase in the lines, are equal by the Tukey's test, at $5 \%$ probability. Coeficient of variation $8.79 \%$. 
WR (LL) showed statistical difference at $0-10 \mathrm{~cm}$ soil depth. Soil moisture contents in the WR, UU, and UM were similar at all depths, suggesting excess water. The WR LM showed higher-soil moisture than WR LL, except at 20-30 cm depth, where they did not differ, suggesting that the root system was not affected. All evaluated components were significant, expressing the distinct temporal behavior of the cover plants subjected to different WRs (Table 2).

Amaranth was the most responsive plant to water because the increase of vegetative components under WR UU, compared to WR LL, was significant for plant height $(77 \%)$, basal area $(157 \%)$, and stem weight $(375 \%)$, in comparison to millet $(11,22$, and $67 \%$, respectively) and quinoa (32\%, 65\% and $120 \%$, respectively) (Figure 2). This suggests that their planting should be anticipated, in order to allow a greater water availability.

The sigmoidal model represented the best fit in all treatments and species for plant height. For stem weight, only amaranth under WR LL showed a quadratic behavior, with decreasing stem weight at 79 DAE. Comparing the values at the inflection point for stem height and weight, in the UU, UM and LM WRs, there were variable results for amaranth (203, 202 , and $180 \mathrm{~cm}$, and 38,34 , and $26 \mathrm{~g}$, respectively), and reduced differences for millet $(888,87$, and $84 \mathrm{~cm}$, and 15,12 , and $14 \mathrm{~g}$, respectively) and quinoa (83, 84 , and $78 \mathrm{~cm}$, and 11,11 , and $9 \mathrm{~g}$, respectively), and they surpassed the WR LL (79 $\mathrm{cm}$ and $9 \mathrm{~g}$ for millet, $63 \mathrm{~cm}$, and $5 \mathrm{~g}$ for quinoa). The height of amaranth plants under the most drastic water regime anticipated the inflection point estimate by six days to initiate the section of the curve with decreasing rates, while quinoa showed a delay of only two days, which corroborates the affirmation that amaranth is less drought tolerant, as previously reported. Biomass and productivity of amaranth can be reduced by up to $50 \%$ under water stress (Mlakar et al., 2012).

The plant basal area had a distinct behavior among the crops (Figure 2), as follows: sigmoidal for quinoa, highlighting WR UM $\left(378 \mathrm{~mm}^{2}\right)$ which was greater than the other WRs $\left(328 \mathrm{~mm}^{2}\right)$. For amaranth, a linear behavior was observed, with daily increments of $4.6 \mathrm{~mm}^{2}$ in WR LM, and $6.3 \mathrm{~mm}^{2}$ in WR UU, confirming its responsiveness to water. Reduced differences were observed between the WRs associated with the linear decrease for millet (mean of $260 \mathrm{~mm}^{2}$, at the end of the cycle). This occurred because, in the first collections, the basal area was evaluated in the $1^{\text {st }}$ node (dilated caulinar region), and with stem growth its elongation caused a decrease in the basal area at connecting point between stem and roots, while for WR LL the reduced tillering (affected by stress) did not promote change in the basal diameter. Quinoa showed the inflection point of sigmoid adjustments (34-38 DAE) very close to the onset of stress (30 DAE), which indicates that this parameter was little affected by stress.

Amaranth's plant height above $2 \mathrm{~m}$ in the WRs UM and UU (Figure 2) was greater than that obtained by Ferreira et al. (2014), who reported a $1.73 \mathrm{~m}$ height in another assay, in the same experimental area, during the rainy season. The basal area in WR LL was stagnant throughout the assay due to stress, whereas the higher WRs responded for the diameter of an herbaceous stem (3.6 cm in the WR UU), in comparison to $1.9 \mathrm{~cm}$ diameter measured by Ferreira et al. (2014) who used the same cultivar.

The sigmoidal inflection point for millet plant height was the earliest (33 DAE), which is coincident with

Table 2. Mean squares and significance levels of the components evaluated according to the source of variation ${ }^{(1)}$.

\begin{tabular}{|c|c|c|c|c|c|c|c|c|c|c|c|c|c|c|}
\hline $\begin{array}{l}\text { Source of } \\
\text { variation }^{(2)}\end{array}$ & $\begin{array}{l}\text { Depth } \\
\text { (D) }\end{array}$ & $\begin{array}{c}\text { Residual } \\
\text { A }\end{array}$ & $\begin{array}{l}\text { Species } \\
\text { (S) }\end{array}$ & $\mathrm{L} \times \mathrm{E}$ & $\begin{array}{c}\text { Residual } \\
\text { B }\end{array}$ & $\begin{array}{c}\text { Collection } \\
\text { (C) }\end{array}$ & $\mathrm{D} \times \mathrm{C}$ & $\mathrm{S} \times \mathrm{C}$ & $\mathrm{D} \times \mathrm{S} \times \mathrm{C}$ & $\begin{array}{c}\text { Residual } \\
\text { C }\end{array}$ & $\begin{array}{c}\text { CV A } \\
(\%)\end{array}$ & $\begin{array}{c}\text { CV B } \\
(\%)\end{array}$ & $\begin{array}{c}\text { CV C } \\
(\%)\end{array}$ & $\mathrm{n}$ \\
\hline Plant height & $157432 * *$ & 80550 & $64943 * *$ & $20627 * *$ & 43978 & $220445^{* *}$ & $3456^{* *}$ & $10923 * *$ & $1025 * *$ & 570432 & 68.54 & 31.01 & 13.18 & 1920 \\
\hline Basal area & $17306872 * *$ & 4149404 & $93172995^{* *}$ & $7752829 * *$ & 5844026 & $38678689 * *$ & $5426841^{* *}$ & $6410260^{* *}$ & $1349503^{*} *$ & 386377963 & 118.04 & 85.78 & 82.30 & 1920 \\
\hline Stem weight & $5975^{* *}$ & 341 & $4544 * *$ & $1127 * *$ & 142 & $9282 * *$ & $349 * *$ & $328 * *$ & $110^{* *}$ & 38 & 127.84 & 82.41 & 42.57 & 1728 \\
\hline No. of leaves & $65577 * *$ & 1615 & $1823833 * *$ & $35379 * *$ & 2091 & $30519 * *$ & $4175^{* *}$ & $21030^{* *}$ & $2810 * *$ & 794 & 77.11 & 87.75 & 54.07 & 1728 \\
\hline WL & $529^{* *}$ & 214 & $2776^{* *}$ & $224 * *$ & 344 & $407 * *$ & $26^{* *}$ & $129 * *$ & $13 * *$ & 9741 & 89.28 & 69.40 & 45.98 & 1728 \\
\hline TSW & $50745^{* *}$ & 14432 & $49804 * *$ & $2510^{\mathrm{ns}}$ & 25676 & $86165^{* *}$ & $4283^{* *}$ & $4458 * *$ & $581 *$ & 627351 & 105.36 & 86.06 & 53.00 & 1728 \\
\hline IW & $14963 * *$ & 2018 & $29162 * *$ & $2125^{* *}$ & 4253 & $26328 * *$ & $1725^{* *}$ & $989 * *$ & $258^{* *}$ & 127211 & 108.18 & 96.18 & 62.06 & 1920 \\
\hline Grain weight & $22683^{* *}$ & 5812 & $6650 * *$ & $534^{\mathrm{ns}}$ & 3282 & $12106^{* *}$ & $1028^{* *}$ & $663 * *$ & $424 * *$ & 31193 & 61.24 & 39.86 & 32.84 & 256 \\
\hline
\end{tabular}

${ }^{(1) n s}$ Nonsignificant. *, **Significant at 5 and $1 \%$ probability, respectively. ${ }^{(2)} \mathrm{WL}$, weight of leaves; TSW, total shoot weight; IW, inflorescence weight. 
the beginning of the variable WR. At the end of the harvest period, the plant height of millet was similar among the WRs (mean of $1.7 \mathrm{~m}$, with maximum difference of $11 \%$ among WRs); however the millet cultivar BRS 1510 has the potential to reach $1.80 \mathrm{~m}$ height (Milheto, 2015b). Barreto et al. (2001) obtained a difference of $29 \%$ for height in millet under water stress, during 36 days, in a greenhouse condition.

The quinoa stem dry weight had the earliest inflection point among the WRs (43 to 56 DAE),

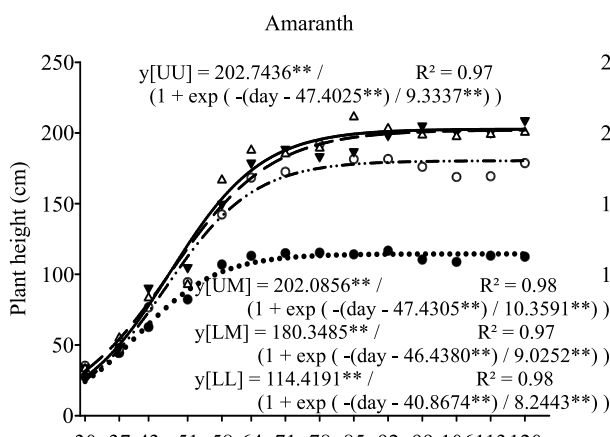

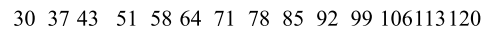

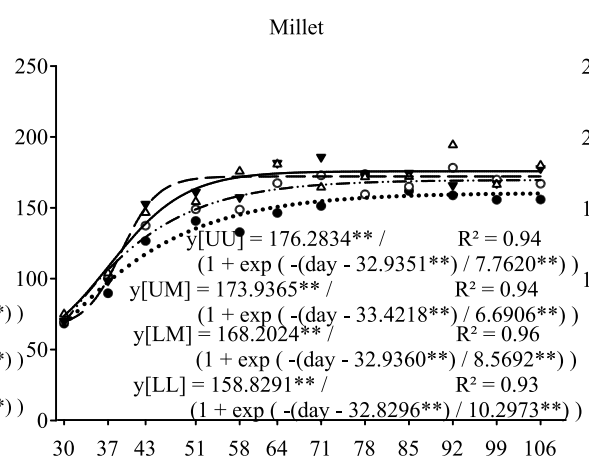

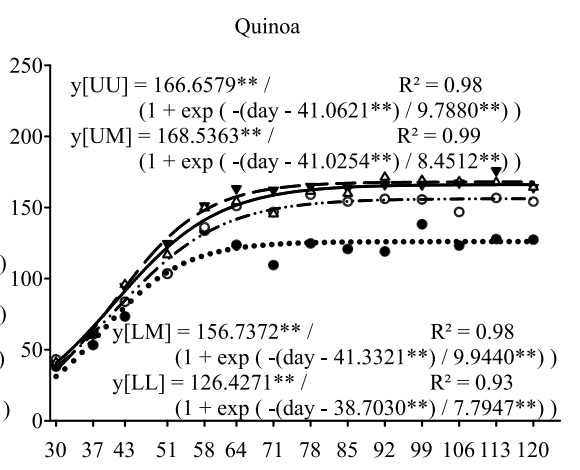
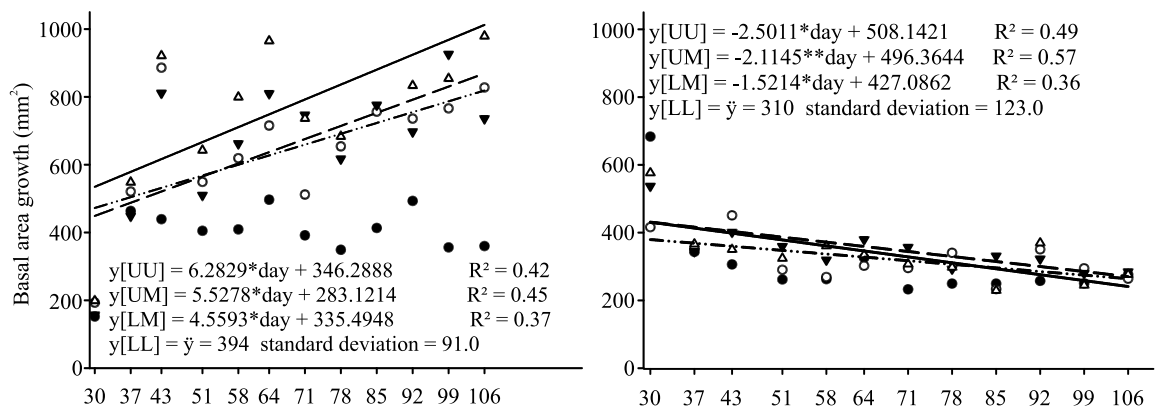

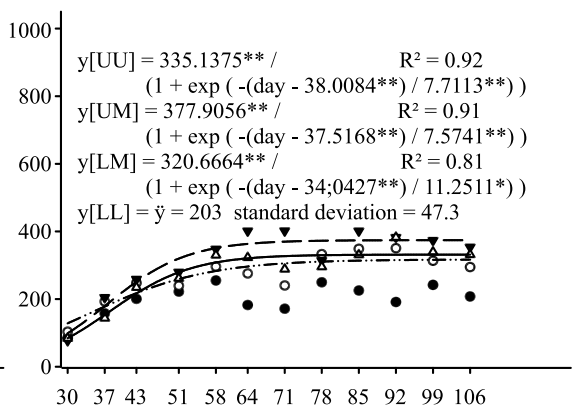

$\begin{array}{llllllllllll}30 & 37 & 43 & 51 & 58 & 64 & 71 & 78 & 85 & 92 & 99 & 106\end{array}$

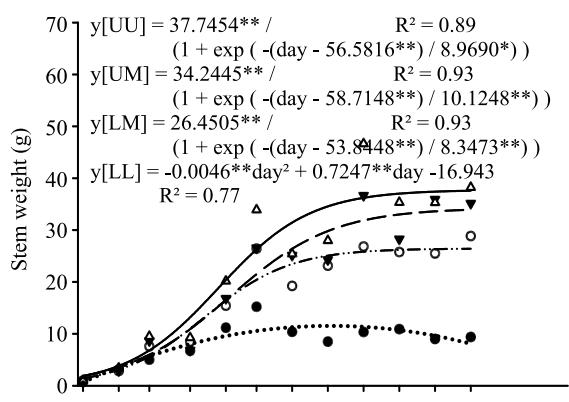

$\begin{array}{llllllllllll}30 & 37 & 43 & 51 & 58 & 64 & 71 & 78 & 85 & 92 & 99 & 106\end{array}$

Days after emergence
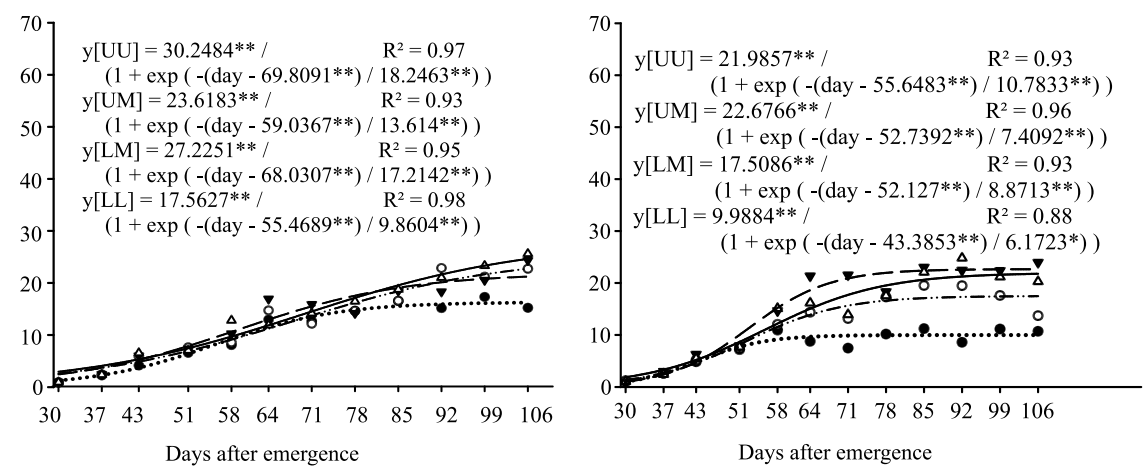

\begin{tabular}{|c|c|}
\hline$\bullet \cdots \cdots \cdots \bullet \bullet(L L)$ & $-\cdots-\cdots-\cdots o(\mathrm{LM})$ \\
\hline
\end{tabular}

Figure 2. Regression of vegetative components of amaranth (Amaranthus cruentus), millet (Pennisetum glaucum), and quinoa (Chenopodium quinoa), under different water regimes (WRs): lower, lower middle, upper middle, and upper WRs correspond to $217,386,563$, and $647 \mathrm{~mm}$ water depths, respectively. 
indicating that the culture had the most determined cycle of the assay. Amaranth was the most responsive, with $30 \mathrm{~g}$ of variation from the lowest mass obtained, in comparison to a WR with largest weight, followed by quinoa (13 $\mathrm{g}$ variation), and millet was the most rustic ( $9 \mathrm{~g}$ variation).

Quinoa and amaranth showed a quadratic behavior for most leaf measurements (Figure 3), as follows: maximum leaf retention between 62 and 83 DAE, for quinoa; and maximum leaf accumulation, between 65 and 92 DAE for amaranth, and between 63 and $68 \mathrm{DAE}$ for quinoa. At $99 \mathrm{DAE}$, leaf measurements of quinoa decreased to nearly zero, irrespective of the WR. For amaranth, leaf numbers stabilized in the WRs LM and UM at 44 and 41 leaves, respectively, at the end of the assay, whereas in the WR UU there was an increasing linear fit, indicating the tendency of the plant to accumulate leaves without signs of senescence, which indicates that in winter there was an extension of the cycle. The water deficit anticipated the maximum values of the amaranth and quinoa leaf measurements, in comparison with the higher water regimes. This would be a natural tendency of stressed plants of reducing the cycle. The maximum values of leaf measurements were associated with the WR UM for quinoa, which may indicate the sensitivity of this species to excess water. The WR UM caused quinoa on the $106^{\text {th }} \mathrm{DAE}$ to retain $40 \%$ more leaves than the $\mathrm{LM}$ and $\mathrm{UU}$ WRs.

Under moderate water stress, some quinoa cultivars close their stomata due to changes in ABA/ cytokinin ratio that affect plant growth (Jacobsen et al., 2009). In addition, water stress at the vegetative stages similar to this assay affects the plant less than the flowering or the filling of grains. In comparison
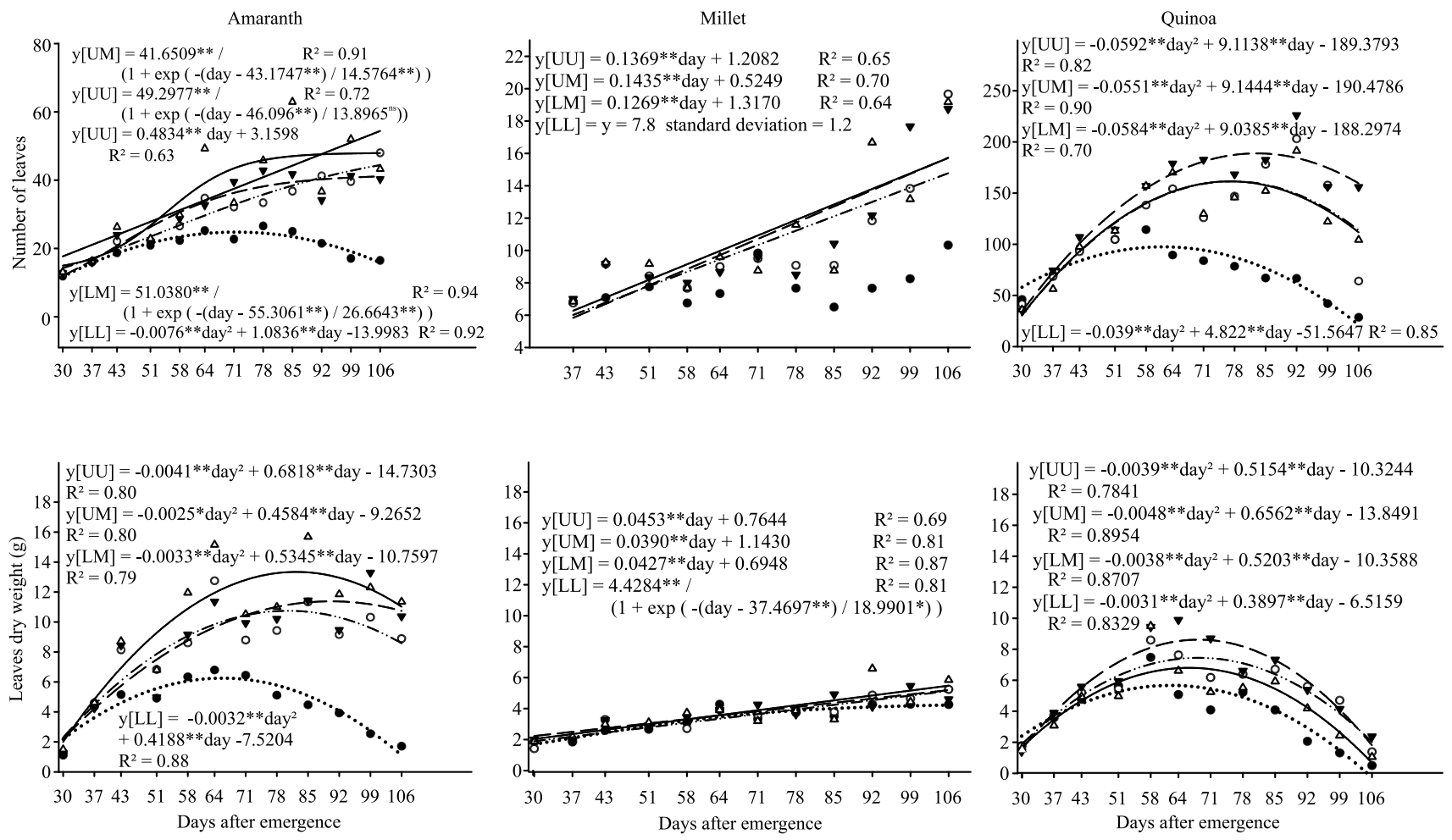

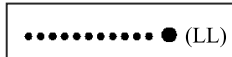

$-\cdots-\cdots \cdots O_{(\mathrm{LM})}$

$---\nabla(\mathrm{UM})$ $\Delta(\mathrm{UU})$

Figure 3. Regression of foliar measurements of amaranth (Amaranthus cruentus), millet (Pennisetum glaucum), and quinoa (Chenopodium quinoa) under different water regimes (WRs): lower, lower middle, upper middle, and upper WRs correspond to $217,386,563$, and $647 \mathrm{~mm}$ water depths, respectively. 
with the pseudocereals, measurements of the vegetative components of millet were restricted to the main stem, that showed reduced variations among the WRs and may be indicative of drought tolerance (Figures 2, 3, and 4), with a predominance of increasing linear adjustments for the number and weight of leaves. The WR LL maintained eight leaves, while the other WRs accumulated 16 leaves until the end of the cycle. The number of leaves for amaranth showed a sigmoidal behavior with inflection at 43 DAE in the LM, UM and UU WRs, surpassing 40 leaves on the $106^{\text {th }} \mathrm{DAE}$, while the WR LL preserved 15 leaves under quadratic behavior. This strategy of maintaining some leaves under stress conditions means ensuring the production of viable seeds although in fewer numbers.

The increase of the number of leaves and the mass reduction in amaranth is justified by the senescence of larger leaves (vegetative phase), and the increase in the number of smaller leaves near the inflorescence. Also, in quinoa, the senescence of larger leaves occurs at the beginning of the cycle, and there is an increase in number of smaller leaves with the inflorescences, to the point that despite the expressive number of 160 leaves in WR UM, their mass was only $2 \mathrm{~g}$.

Under water deficit, foliar reduction is considered a frequent physiological response derived from the inhibition of cell expansion. This is due to reduced stomatal opening of the plants, which limits the absorption of $\mathrm{CO}_{2}$ and reduces photosynthesis under severe water stress (Osakabe et al., 2014). This adaptation mechanism preserves the soilwater supply for a longer period due to reduced transpiration; however, under prolonged water deficit, leaf abscission is stimulated (Mickelbart et al., 2013).

As to leaf weight (more photosynthetically active region), the results indicate a high responsiveness to the addition of water in amaranth (6 to $12 \mathrm{~g}$ ), which occurred on a smaller scale for quinoa (6 to $9 \mathrm{~g}$ ), and in contrast to the lower response to irrigation of millet (maximum of $5.6 \mathrm{~g}$ ). This means that amaranth may be the favored cover crop in rainier regions. After 70 days, the senescence process for the pseudocereals occurred, which did not occur in millet. This means that selection of millet or amaranth as a cover crop may depend on the the synchronization between the release of nutrients from these plants to the sucession crop. Also, regarding leaf weight, there were no millet responses to water addition, which suggests rusticity of the species and may be an advantage in dry regions.

Observing the trends of Figure 4, the pseudocereals were similar for shoot weight at $106 \mathrm{DAE}$, in the most stressed treatment, and both showed lower values for this variable than millet. However, this more stressed level is lower than which normally occurs at the end of the rainy season in the Cerrado, when cover plants are usually planted. From the second stress level, amaranth was similar to the control plant, that is, millet. Quinoa obtained the lowest shoot weight among the studied materials, after the second level of irrigation. This result indicates amaranth as a potential cover plant. Quinoa, however, should have an improved management to act as a cover plant.

In a more detailed data observation, the total shoot weight at 106 DAE highlights the greatest biomass of millet plants (main stem and tillers with $109 \mathrm{~g}$ in WR UM, and $111 \mathrm{~g}$ in WR UU), followed by amaranth (WR UU with $103 \mathrm{~g}$ ), whereas quinoa accumulated a maximum of $62 \mathrm{~g}$ in the WR UM, which is $25 \%$ higher than the WR UU. As to the management, this weight accumulation corresponds to the best season for desiccation, which should be synchronized with the next planting. This advantage of millet may be due to root aggressiveness as showed by Jimenez et al. (2008), who compared millet with quinoa in a greenhouse, where the millet stood out mainly for its root system, even in a compactedsoil treatment. The total shoot weight is important for a cover plant, however, other attributes such as the $\mathrm{C} / \mathrm{N}$ and lignin/ $\mathrm{N}$ ratios should be considered as they affect mineralization and immobilization (Carvalho et al., 2015).

Petter et al. (2013) evaluated millet hybrids subjected to four WRs and highlighted the accumulation of the millet biomass $(60 \%$ in the stem) and the superiority of the root system volume, in comparison to other species. There were also no statistical differences between WR for the biomass of plants and their parts. The marked volume of the millet root, which can exploit higher soil volume, may have helped to maintain the water levels of the plants, considering that, in WR LL there was $15 \%$ moisture in the soil between 0.10 and $0.30 \mathrm{~m}$ 
soil depth (Table 1). The vegetative predisposition of millet during the winter was confirmed by the reduced weight of inflorescences, in relation to the total shoot weight (18\%), in the comparison with amaranth (63\%) and quinoa (55\%). Ferreira et al. (2014) found similar relationships for amaranth ranging from 52 to $65 \%$. The high-weight accumulation of apical inflorescence of amaranth, and its reduced stem woodiness caused accentuated lodging in the WR LM, UM and UU, despite the

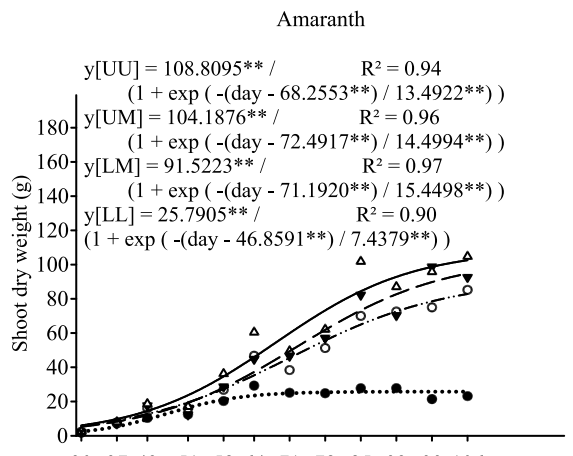

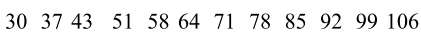

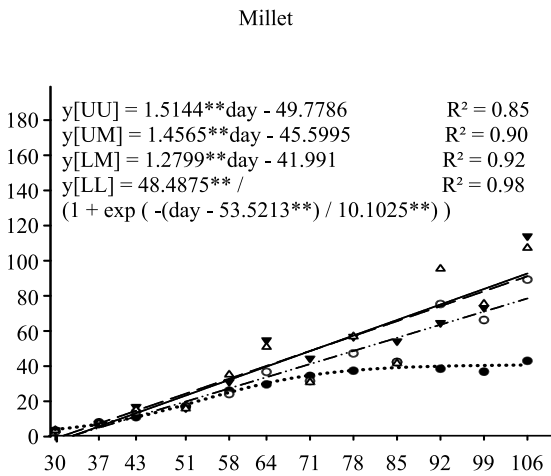

$\begin{array}{llllllllllll}30 & 37 & 43 & 51 & 58 & 64 & 71 & 78 & 85 & 92 & 99 & 106\end{array}$

Quinoa

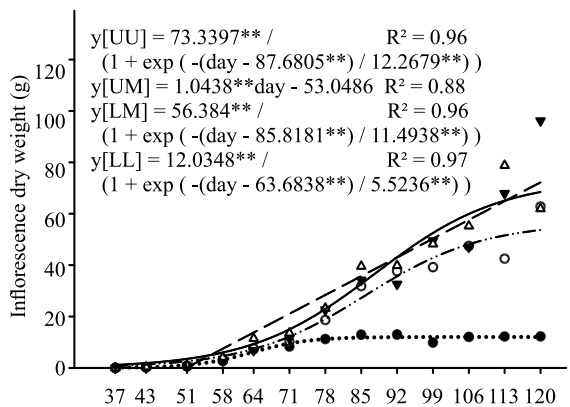

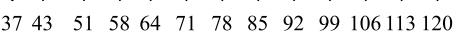

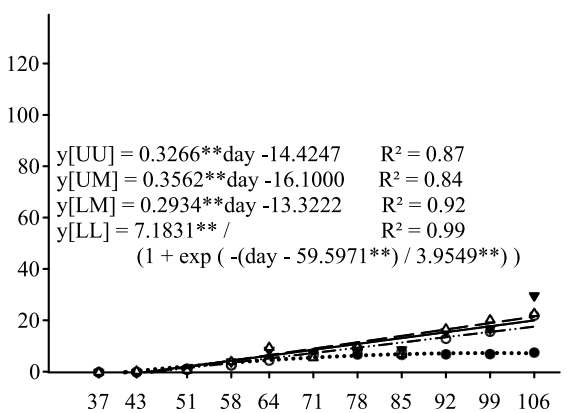

$\begin{array}{lllllllllll}37 & 43 & 51 & 58 & 64 & 71 & 78 & 85 & 92 & 99 & 106\end{array}$

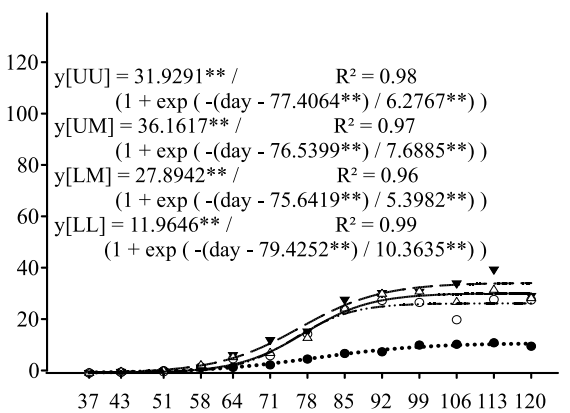

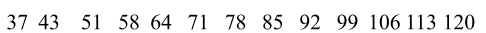
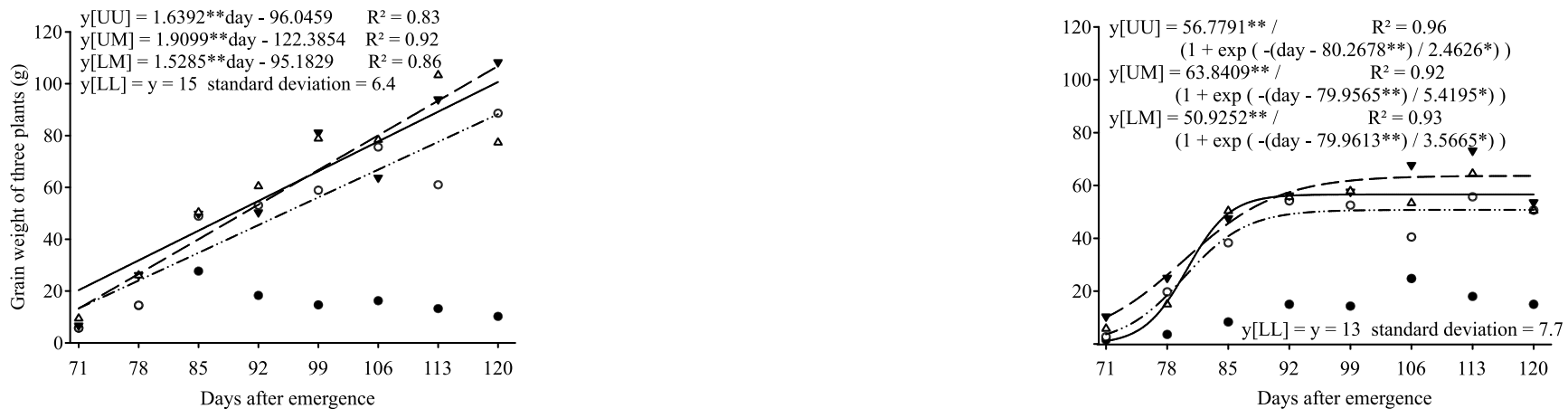

$\ldots \ldots \cdots \cdot \bullet_{(\mathrm{LL})} \quad-\cdots-\cdots-\cdots \mathrm{o}_{(\mathrm{LM})} \quad-\boldsymbol{-}-\boldsymbol{\nabla}(\mathrm{UM}) \quad \Delta(\mathrm{UU})$

Figure 4. Regression of productive components of amaranth (Amaranthus cruentus), millet (Pennisetum glaucum), and quinoa (Chenopodium quinoa) under different water regimes (WRs): lower, lower middle, upper middle, and upper WRs correspond to $217,386,563$, and $647 \mathrm{~mm}$ water depths, respectively. 
pronounced diameter of the basal area. Considering that thinning of 10 plants per meter for the pseudocereals is maintained, tests are suggested to avoid lodging, to maintain the adequate population, or to use growth reducers, although this may not be a suitable strategy for the production of biomass.

The WR UM had no sigmoidal adjustment for the amaranth inflorescence mass and differed from the other WRs, as the data behavior showed a tendency for exponential growth. Linear adjustment was selected for the WR UM, which showed an increase of more than $1 \mathrm{~g}$ per day, while the same WR promoted quinoa to a final accumulation of $36 \mathrm{~g}$ during 69 days ( $0.5 \mathrm{~g}$ per day).

Grains were husked from 71 to 120 DAE to evaluate the progression of grain filling. There was no adjustment for the quinoa grain mass in WR LL, while the other WRs showed the same inflectionpoint time (80 DAE), with a grain weight in WR UM 12\% higher than that in WR UU. Amaranth grain weight was not adjusted for WR LL, and the other WRs showed linear increments superior to $1.5 \mathrm{~g}$ per day, especially WR UM at $1.9 \mathrm{~g}$ per day.

Linear increases for biomass accumulation in the amaranth grains for the WR LM, UM and UU, and also for inflorescence in WR UM, indicate that the complete maturation of grains of this species cultivated during winter could exceed 120 DAE. Ferreira et al. (2014) obtained complete grain maturation at $90 \mathrm{DAE}$, when the species was grown during the summer. Sigmoidal growth for amaranth grain accumulation was only adjusted by bringing together the mean mass of all WRs, which resulted in $67 \mathrm{~g}$ at the end of the assay.

The analysis of all components indicates that the WR UU is superior to the others. Amaranth shows superiority of the WR UU for most components (vegetative and foliar measurements); however the inflorescences and grains show superiority of the WR UM. For quinoa, the WR UM is superior for all evaluated components, indicating that this crop may be sensitive to excess water, or demand soil aeration, despite the reduced differences in soil moisture between WR UM and UU at depths up to $0.30 \mathrm{~m}$ (Table 1).

Costa et al. (2005) observed that the millet cultivation during the winter prolongs the crop cycle and reduces both growth and weight due to sensitivity of the species to the photoperiod and thermoperiod, which justifies the various productive components that showed linear increase until 106 DAE. The appearance of sterile millet plants was observed at low temperatures $\left(13\right.$ to $\left.16^{\circ} \mathrm{C}\right)$, in the pre-flowering period (Mashingaidze \& Muchena, 1982). In the flowering induction period for millet (43 to $60 \mathrm{DAE}$ ), 115 hours of temperatures below $16^{\circ} \mathrm{C}$ were registered, mostly between midnight and seven o'clock in the morning. Therefore, millet 'BRS 1501' showed sensitivity to low temperatures, inhibiting grain production in the ears.

According to Ong \& Monteith (1985), during the second stage of millet growth, the determination of the number of viable flowers in the spikelets depends on the reproductive system to identify the favorable rate of growth per unit of time, which can be expressed in grams of dry matter per day (or megajoules per day), and is strongly correlated with the amount of intercepted radiation (determination of the assimilated supply) per plant and by the thermal period (determination of the development rate) in anthesis.

A study on climatic data from the collection sites of a germplasm bank in India, with more than 22,000 accessions, revealed that most materials from

Table 3. Compilation of the models and coefficient of determination $\left(\mathrm{R}^{2}\right)$ adjusted for amaranth (Amaranthus cruentus), millet (Pennisetum glaucum), and quinoa (Chenopodium quinoa) in plant components, productive and foliar measurements.

\begin{tabular}{|c|c|c|c|c|c|c|c|c|}
\hline \multirow[t]{2}{*}{ Crop } & \multicolumn{4}{|c|}{ Number of models } & \multirow[t]{2}{*}{ Total } & \multicolumn{3}{|c|}{ Mean of the coefficient of determination $\left(\mathrm{R}^{2}\right)$} \\
\hline & Undetermined & Linear & Quadratic & Sigmoidal & & Linear & Quadratic & Sigmoidal \\
\hline Amaranth & 2 & 7 & 6 & 17 & 32 & 0.72 & 0.83 & 0.93 \\
\hline Millet & 3 & 26 & 7 & 16 & 52 & 0.78 & 0.84 & 0.95 \\
\hline Quinoa & 2 & - & 8 & 22 & 32 & - & 0.83 & 0.94 \\
\hline Total & 7 & 33 & 21 & 55 & 116 & 0.75 & 0.83 & 0.94 \\
\hline
\end{tabular}


latitudes between 10 and $20^{\circ}$, on both sides of the Equator, are highly sensitive to longer photoperiods $\left(>12.5\right.$ hours) and to lower temperatures $\left(<12^{\circ} \mathrm{C}\right)$ (Upadhyaya et al., 2012). In experiments with different irrigation levels, it is imperative that water be the main limiting factor. Millet 'BRS 1501' was outstanding for the biomass production in comparison to the other cultivars (Costa et al., 2005). The authors obtained yields between 1 and $2.8 \mathrm{Mg} \mathrm{ha}^{-1}$ for this cultivar planted during two seasons (January and March 2002), with an average temperature of $26^{\circ} \mathrm{C}$, without affecting floral induction of the crop. For 'BRS 1501', maturation is predicted at 120 days (Milheto, 2015a). It was not possible to extend the measurements after September for the cultivation during the winter due to the possibility of rainfall in October.

It should be noted that millet was also superior to the other evaluated materials in the most limiting WRs (Figures 3 and 4), showing that millet is still the most recommended species for straw production for the no-tillage system, as, in addition to protecting the soil, it decreases resistance to soil penetration (Pires et al., 2008).

Linear models were predominant to explain the behavior of millet with mean determination coefficient of 0.78 (Table 3). For amaranth and quinoa, the behavior was explained mainly by the sigmoid models, followed by the linear model for amaranth, and the quadratic model for quinoa.

Considering the beginning of differential irrigation at $30 \mathrm{DAE}$, it was observed that the mean inflection point of the sigmoid adjustments of 14 components, associated with WR LL, was 50 DAE, while in the other WRs the average occurred at 59 DAE. This may be an indication that adequate water supply favored the incremental period of the evaluated components at increasing rates; and, at the end of the assay, the components evaluated under sigmoidal fit in the WRs LM, UM and UU surpassed the values showed in WR LL by $225 \%$. This dynamic should have occurred due to a reduced cycle resulting from stress.

Plant growth and biomass can be asymmetric and represented by the Gompertz (Damgaard \& Weiner, 2008; Qiming et al., 2008) or Richards function; however, the high mean obtained for the coefficients of determination of the symmetrical sigmoidal models fitted in this assay (0.94) is sufficient to compare with the linear (0.75) and quadratic models (0.83).

The dynamics of plant growth in the rainy $(1071 \mathrm{~mm})$ and dry $(200 \mathrm{~mm})$ seasons showed asymmetric (Gompertz) and symmetric sigmoidal models (logistic), respectively, neglecting the linear models (Rodriguez et al., 2011). The authors observed that the symmetric sigmoidal model showed the best fit for assessing water regimes in the dry season.

\section{Conclusions}

1. The dynamics of species growth - amaranth (Amaranthus cruentus), quinoa (Chenopodium quinoa), and millet (Pennisetum glaucum) - varies according to the water regime adopted.

2. Amaranth tends to show the highest biomass production, at the highest water levels, and is the most responsive to irrigation.

3. Millet shows the highest growth and biomass production at the highest-stress level, and shows smaller differences between water regimes than the pseudocereals.

\section{Acknowledgments}

To Coordenação de Aperfeiçoamento de Pessoal de Nível Superior (Capes), for scholarship granted to the first author; and to Conselho Nacional de Desenvolvimento Científico e Tecnológico (CNPq), for the scientific productivity fellowships granted to the third author.

\section{References}

ACOMPANHAMENTO DA SAFRA BRASILEIRA [DE] GRÃOS: safra 2014/15: décimo segundo levantamento, v.2, n.12, set. 2015. 134p. Available at: <http://www.conab.gov.br/ OlalaCMS/uploads/arquivos/15_09_11_08_57_48_boletim_ graos_setembro_2015.pdf $>$. Accessed on: Nov. $28201 \overline{6}$.

ASSAD, E.D.; SANO, E.E.; MASUTOMO, R.; CASTRO, L.H.R. de; SILVA, F.A.M. da. Veranicos na região dos cerrados brasileiros, frequência e probabilidade de ocorrência. Pesquisa Agropecuária Brasileira, v.28, p.993-1003, 1993.

BARRETO, G.P.; LIRA, M. de A.; SANTOS, M.V.F. dos; DUBEUX JÚNIOR, J.C.B. Avaliação de clones de capim-elefante (Pennisetum purpureum Schum.) e de um híbrido com o milheto (Pennisetum glaucum (L.) R. Br.) submetidos a estresse hídrico. 1. Parâmetros morfológicos. Revista Brasileira de Zootecnia, v.30, p.1-6, 2001. DOI: 10.1590/S1516-35982001000100001. 
CARVALHO, A.M. de; COSER, T.R.; REIN, T.A.; DANTAS, R. de A.; SILVA, R.R.; SOUZA, K.W. Manejo de plantas de cobertura na floração e na maturação fisiológica e seu efeito na produtividade do milho. Pesquisa Agropecuária Brasileira, v.50, p.551-561, 2015. DOI: 10.1590/S0100-204X2015000700005.

CHOUKR-ALLAH, R.; RAO, N.K.; HIRICH, A.; SHAHID, M.; ALSHANKITI, A.; TODERICH, K.; GILL, S.; BUTT, K.U.R. Quinoa for marginal environments: toward future food and nutritional security in MENA and Central Asia regions. Frontiers in Plant Science, v.7, art. 346, 2016. DOI: 10.3389/ fpls.2016.00346.

COSTA, A.C.T. da; GERALDO, J.; PEREIRA, M.B.; PIMENTEL, C. Unidades térmicas e produtividade em genótipos de milheto semeados em duas épocas. Pesquisa Agropecuária Brasileira, v.40, p.1171-1177, 2005. DOI: 10.1590/S0100204X2005001200003.

COSTA, A.C.T. da; PRIESNITZ, R. Influência do arranjo espacial do milheto em relação aos estádios fenológicos e unidades térmicas. Global Science and Technology, v.7, p.37-47, 2014. DOI: 10.14688/1984-3801/gst.v7n1p37-47.

DAMGAARD, C.; WEINER, J. Modeling the growth of individuals in crowded plant populations. Journal of Plant Ecology, v.1, p.111-116, 2008. DOI: 10.1093/jpe/rtn008.

FERREIRA, C.C.; RIBEIRO JÚNIOR, W.Q.; RAMOS, M.L.G.; SPEHAR, C.R.; FARIAS, T.R.R. Efeito da densidade de semeadura e doses de nitrogênio sobre a produtividade e biometria de amaranto, no Cerrado do Planalto Central. Bioscience Journal, v.30, p.534-546, 2014.

FGHIRE, R.; ANAYA, F.; ALI, O.I.; BENLHABIB, O.; RAGAB, R.; WAHBI, S. Physiological and photosynthetic response of quinoa to drought stress. Chilean Journal of Agricultural Research, v.75, p.174-183, 2015. DOI: 10.4067/S071858392015000200006.

HANKS, R.J.; KELLER, J.; RASMUSSEN, V.P.; WILSON, G.D. Line source sprinkler for continuous variable irrigation crop production studies. Soil Science Society of America Journal, v.40, p.426-429, 1976. DOI: 10.2136/ sssaj1976.03615995004000030033x.

HIRICH, A.; CHOUKR-ALLAH, R.; JACOBSEN, S.-E. Quinoa in Morocco - effect of sowing dates on development and yield. Journal of Agronomy and Crop Science, v.200, p.371-377, 2014. DOI: $10.1111 /$ jac.12071.

HÝSKOVÁ, V.D.; MIEDZIŃSKA, L.; DOBRÁ, J.; VANKOVA, R.; RYŠLAVÁ, H. Phosphoenolpyruvate carboxylase, NADPmalic enzyme, and pyruvate, phosphate dikinase are involved in the acclimation of Nicotiana tabacum L. to drought stress. Journal of Plant Physiology, v.171, p.19-25, 2014. DOI: 10.1016/j. jplph.2013.10.017.

JACOBSEN, S.-E.; LIU, F.; JENSEN, C.R. Does root-sourced ABA play a role for regulation of stomata under drought in quinoa (Chenopodium quinoa Willd.). Scientia Horticulturae, v.122, p.281-287, 2009. DOI: 10.1016/j.scienta.2009.05.019.

JIMENEZ, R.L.; GONÇALVES, W.G.; ARAÚJO FILHO, J.V. de; ASSIS, R.L. de; PIRES, F.R.; SILVA, G.P. Crescimento de plantas de cobertura sob diferentes níveis de compactação em um Latossolo Vermelho. Revista Brasileira de Engenharia Agrícola e Ambiental, v.12, p.116-121, 2008. DOI: 10.1590/ S1415-43662008000200002.

KHAN, H.R.; PAULL, J.; SIDDIQUE, K.H.M.; STODDARD, F.L. Faba bean breeding for drought-affected environments: a physiological and agronomic perspective. Field Crops Research, v.115, p.279-286, 2010. DOI: 10.1016/j.fcr.2009.09.003.

LAVINI, A.; PULVENTO, C.; D'ANDRIA, R.; RICCARDI, M.; CHOUKR-ALLAH, R.; BELHABIB, O.; YAZAR, A.; INCEKAYA, Ç.; METIN SEZEN, S.; QADIR, M.; JACOBSEN, S.-E. Quinoa's potential in the Mediterranean region. Journal of Agronomy and Crop Science, v.200, p.344-360, 2014. DOI: 10.1111/jac.12069.

LIU, F.; STÜTZEL, H. Biomass partitioning, specific leaf area and water use efficiency of vegetable amaranth (Amaranthus spp.) in response to drought stress. Scientia Horticulturae, v.102, p.1527, 2004. DOI: 10.1016/j.scienta.2003.11.014.

LIU, F.; STÜTZEL, H. Leaf expansion, stomatal conductance, and transpiration of vegetable amaranth (Amaranthus sp.) in response to soil drying. Journal of the American Society for Horticultural Science, v.127, p.878-883, 2002.

MASHINGAIDZE, K.; MUCHENA, S.C. The induction of floret sterility by low temperature in pearl millet (Pennisetum typhoides (Burm.) Stapf. and Hubbard) [Zimbabwe]. Rhodesian Journal of Agricultural Research, v.20, p.29-37, 1982.

MICKELBART, M.V.; HASEGAWA, P.M.; SALT, D.E. Respostas e adaptação ao estresse abiótico - as mudanças fenotípicas na estrutura e no comportamento foliares são importantes respostas ao estresse. In: TAIZ, L.; ZEIGER, E. Fisiologia vegetal. 5.ed. Porto Alegre: ArtMed, 2013. p.763-767.

MILHETO - BRS 1501. Available at: <https://www.embrapa.br/ busca-de-produtos-processos-e-servicos/-/produto-servico/233/ milheto---brs-1501>. Accessed on: Dec. $12015 \mathrm{a}$.

MILHETO: variedade de milheto BRS 1501. Available at: $<$ http:// www.cnpms.embrapa.br/milheto/br1501.html>. Accessed on: Dec. $12015 b$.

MLAKAR, S.G.; BAVEC, M.; JAKOP, M.; BAVEC, F. The effect of drought occurring at different growth stages on productivity of grain amaranth Amaranthus cruentus G6. Journal of Life Sciences, v.6, p.283-286, 2012.

MONITORAMENTO de irrigação no Cerrado. Planaltina: Embrapa Cerrados, 2016. Software para uso eficiente da água e economia na irrigação em cultivos no Cerrado. Available at: $<$ http://hidro.cpac.embrapa.br/index.php $>$. Accessed on: Feb. 23 2016.

ONG, C.K.; MONTEITH, J.L. Response of pearl millet to light and temperature. Field Crops Research, v.11, p.141-160, 1985. DOI: 10.1016/0378-4290(85)90098-X.

OSAKABE, Y.; OSAKABE, K.; SHINOZAKI, K.; LAM-SON, P.T. Response of plants to water stress. Frontiers in Plant Science, v.5, p.1-8, 2014. DOI: 10.3389/fpls.2014.00086.

PEREIRA FILHO, I.A. Cultivo do milheto: apresentação. 4.ed. Sete Lagoas: Embrapa Milho e Sorgo, 2009. (Embrapa Milho e Sorgo. Sistema de produção, 2009). Available at: $<$ http://www. 
cnpms.embrapa.br/publicacoes/milheto_4_ed/index.htm>. Accessed on: Aug. 62013.

PETTER, F.A.; PACHECO, L.P.; ZUFFO, A.M.; PIAUILINO, A.C.; XAVIER, Z.F.; SANTOS, J.M. dos; MIRANDA, J.M. de S. Desempenho de plantas de cobertura submetidas à déficit hídrico. Semina: Ciências Agrárias, v.34, p.3307-3320, 2013. Suplemento 1. DOI: $10.5433 / 1679-0359.2013 v 34 n 6 S u p 11 p 3307$.

PIRES, F.R.; ASSIS, R.L. de; PROCÓPIO, S. de O.; SILVA, G.P.; MORAES, L.L.; RUDOVALHO, M.C.; BÔER, C.A. Manejo de plantas de cobertura antecessoras à cultura da soja em plantio direto. Revista Ceres, v.55, p.94-101, 2008.

QIMING, L.; SCHNEIDER, M.K.; PITCHFORD, J.W. Individualism in plant populations: using stochastic differential equations to model individual neighbourhood-dependent plant growth. Theoretical Population Biology, v.74, p.74-83, 2008. DOI: 10.1016/j.tpb.2008.05.003.

RODRIGUEZ, L.; TORRES, V.; MARTÍNEZ, R.O.; JAY, O.; NODA, A.C.; HERRERA, M. Models to estimate the growth dynamics of Pennisetum purpureum cv. Cuba CT-169. Cuban Journal of Agricultural Science, v.45, p.349-354, 2011.

SPEHAR, C.R.; ROCHA, J.E. da S.; RIBEIRO JÚNIOR, W.Q.; SANTOS, R.L. de B.; ASCHERI, J.L.R.; SOUZA, F.F. de J. Avances y desafíos de la producción y utilización de la quinua en
Brasil. In: BAZILE, D. (Coord.). Estado del arte de la quinua en el mundo en 2013. Santiago: FAO, 2014. p.681-706.

SPEHAR, C.R.; TEIXEIRA, D.L.; LARA CABEZAS, W.A.R.; ERASMO, E.A.L. Amaranto BRS Alegria: alternativa para diversificar os sistemas de produção. Pesquisa Agropecuária Brasileira, v.38, p.659-663, 2003.

SPEHAR, C.R.; TRECENTI, R. Desempenho agronômico de espécies tradicionais e inovadoras da agricultura em semeadura de sucessão e entressafra no Cerrado do Planalto Central Brasileiro. Bioscience Journal, v.27, p.102-111, 2011.

TEIXEIRA, D.L.; SPEHAR, C.R.; SOUZA, L.A.C. Caracterização agronômica de amaranto para cultivo na entressafra no Cerrado. Pesquisa Agropecuária Brasileira, v.38, p.45-51, 2003. DOI: 10.1590/S0100-204X2003000100006.

THE WORLD sorghum and millet economies: facts, trends and outlook. Rome: FAO, 1996. Available at: <http://www.fao.org/ docrep/w1808e/w1808e00.htm\#Contents $>$. Accessed on: Aug. 3 2013.

UPADHYAYA, H.D.; REDDY, K.N.; IRSHAD-AHMED, M.; DRONAVALLI, N.; GOWDA, C.L.L. Latitudinal variation and distribution of photoperiod and temperature sensitivity for flowering in the world collection of pearl millet germplasm at ICRISAT genebank. Plant Genetic Resources, v.10, p.59-69, 2012. DOI: $10.1017 / \mathrm{S} 1479262111000979$.

Received on April 11, 2016 and accepted on November 28, 2016 